\title{
Evaluating Public Forestry Investments in British Columbia: The Choice of Discount Rates
}

\author{
G. H. Manning ${ }^{\prime \prime}$ \\ Pacific Forest Research Centre, Victoria, B.C.
}

\begin{abstract}
In the face of a growing demand for wood fibre from British Columbia forests, intensive public-sector forestry investments may be required. That these investments must compete with others, which may not have as their major objective economic optimization, makes analysis and comparison on a common basis difficult. The choice of discount rate to be used in analysis is critical. One solution is a dual rate approach, with a "social discount rate" being used for long range investments affecting future generations, and a more normal rate being used for harvest scheduling.
\end{abstract}

\section{Résumé}

La demande croissante de fibres ligneuses imposée aux forêts de la Colombie-Britannique obligera le secteur public à effectuer des investissements intensifs en foresterie. Le fait que de tels investissements doivent en concurrencer d'autres qui peuvent ne pas avoir pour principal objectif d'optimiser l'économie, rend difficiles l'analyse et la comparaison sur une base courante. Le choix du taux d'escompte à utiliser dans l'analyse est critique. Une solution serait d'envisager un taux double, soit un "taux d'escompte social" pour les investissements de longue portée qui affectent les générations futures et un taux plus normal pour les programmes d'exploitation.

\section{Introduction}

While in many parts of the world, demand for wood fibre exceeds supply, Canada still possesses major reserves of high-quality fibre (Persson 1974). Various forecasts, such as those reviewed by Keays (1975) and Jaakko Pöyry \& Co. (1975), suggest that Canada, and especially British Columbia, will become an even more important world source of wood fibre than at present.

The United States, absorbing $75 \%$ of Canada's forest products exports, and more than half of B.C.'s exports, is Canada's largest market. Recent forecasts prepared by the U.S. Forest Service (1975) for the Resource Planning Act assessment suggest that imports of forest products from Canada will form an increasingly large proportion of U.S. consumption. For example, softwood lumber imports from Canada are forecast to reach about $36 \%$ of total domestic consumption in the United States by the year 2000 .

What do such forecasts mean in terms of the impact on B.C. forest resources, and what will this impact mean in terms of resource management options open to this province and the remainder of Canada? TThe author wishes to thank H. H. Webster, G. Thornburn, E. A. F.
Wetton and Alan Teskey for their helpful comments; although responsibility for errors or omissions rests with the author.

\section{Timber Requirements, Availability and Intensified Forest Management}

If Canada is to experience the increased U.S. sales which have been forecast by the year 2000 , annual harvest will be nearly 5 billion cubic feet (141.6 million $\mathrm{m}^{3}$ ) for this market alone, with a total roundwood harvest of 9.1 billion cubic feet (257.8 million $\mathrm{m}^{3}$ ).

Canada presently has a net allowable cut on all inventoried forest land of 8.23 billion cubic feet (233.1 million $\mathrm{m}^{3}$ ) per year. Harvest of roundwood (excluding fire and disease) in Canada in 1973 was 5.1 billion cubic feet $\left(144.5\right.$ million $\mathrm{m}^{3}$ ), with softwoods accounting for 4.6 billion cubic feet (130.3 million $\mathrm{m}^{3}$ ) of this amount. B.C. contributed 2.5 billion cubic feet $\left(70.8\right.$ million $\left.\mathrm{m}^{3}\right)$ of the total softwood harvest, or $54 \%$. On the basis of present allowable cut ${ }^{2}$, and forecasts of forest products demand (based on present prices), Canada will likely achieve, on a national basis, a balance in harvest and allowable cut before the year 2000.

F. L. C. Reed and Associates (1973), on the basis of 1967 inventory statistics, estimated that Canada has a surplus of 4 billion cubic feet (113.3 million $\mathrm{m}^{3}$ ) per year of harvestable timber. Of this, $75 \%$ is composed of coniferous species, and of this $75 \%$, B.C. has 1.2 billion cubic feet ( 34 million $\mathrm{m}^{3}$ ), or $40 \%$.

Even given the present mature inventory and current allowable cut, it will prove necessary for B.C. to make substantial investments in intensified forest management if it wishes to remain a major participant in growing forest products markets.

Examples of this type of investment are numerous. One prime example is the large acreage of not sufficiently restocked (N.S.R.) land in the province. Four per cent of all forest land in approved Public Sustained Yield Units is N.S.R., while another $2 \%$ is under non-commercial cover.

Another problem is the rehabilitation of decadent cedar-hemlock stands. While not significant on a province-wide basis, in many parts of the interior "wet-belt" these stands occupy the best sites. However, production on these sites is negligible. Worse yet, much of this decadent cedarhemlock is in "residual" stands, which have already been high-graded to retrieve that material which is merchantable. The per acre cost of site rehabilitation in such cedar-hemlock stands could exceed $\$ 300$ (Dobie 1976).

2Allowable cut is not a static concept, and is subject to substantial change over the years. As technology changes, allowable cut will increase, as it will as more of Canada's forest land is inventoried. On the other hand, we may expect continued withdrawals for various purposes such as parks, urban sprawl and hydro development. Further restrictions on forestry practices may reduce allowable cut. 
Investments in programs such as these must compete for funding with other public programs which may appear equally attractive. While many forestry investments are financially attractive ${ }^{3}$, governments are usually not interested in financial objectives alone, but rather various other economic and social goals, only some of which may be analyzed via conventional economic methods. McKillop (1976), for example, describes the necessity of integrating economic programs such as public forestry investments with various social goals and objectives, under a system of social and economic constraints. The remainder of this paper investigates some of the economic problems of coming to grips with such integration, suggesting manipulation of the public discount rate as one approach.

\section{Social Goals, Economic Goals and Social Welfare}

It is generally stated that the ultimate aim of public policy (that is, public expenditure) is maximization of social welfare. Within the economic theory, a number of criteria have evolved by which social welfare may be measured.

The basic criterion which has developed is the concept of the "Pareto Optimum", the essence of which is that a policy (or expenditure) increases social welfare if at least one person is made "better-off" and nobody is made "worse-off". A number of permutations of this basic principle have been developed, including rationalization of the effects of taxes, subsidies, level of competition, and opportunity or compensation for "losers".

It is not the intention of this paper to review these, and the reader is referred to Henderson and Quandt (1971: 254-292) for a comprehensive review of welfare criteria. However, benefit-cost analysis, stemming from the broad field of welfare economics has become the technique by which economists compare the relationship of social benefits to social costs for a range of government (or social) investments. In the application of benefit-cost analysis to public investment, the problem of varying time-frames becomes important. The economist's "fix" for this is the discount rate, which brings costs and returns to a common point in time. Because of the way in which discount rates are mathematically derived, the inter-relation between time-frame and discount rate is crucial in determining the ranking which various social investments receive.

\section{Welfare Maximization and the Discount Rate}

Given that government goals are welfare- rather than profit-oriented, the choice of an appropriate discount rate for economic analysis of forestry investment programs becomes much more difficult. If profit maximization were the goal, the use of the current market rate of interest would suffice. However, given the welfare orientation of government goals, some other - likely lower - rate should be used. ${ }^{4}$

A further difficulty with the market rate in analyzing government programs is the current high interest rate. Webster and Gordon (1975) show that use of high interest rates militates against programs with long-term payoffs, such as is the case in many forestry programs. Thus, when forestry investments compete for limited funds with other programs with quicker payoffs, they seem unattractive.

Earlier debate by foresters as to the choice of an appropriate discount rate with which to evaluate public forestry investments was represented by two viewpoints. The first of these propounded by Fernow (1902) and Roth (1916), was that the discount rate should be keyed to physical growth rates of some "normal" forest. They saw forestry as an end in itself.

The second approach disposed of the whole problem of an appropriate discount rate by dismissing it out-of-hand. Fritz (1931) and Oxholm (1931) were representative of this viewpoint, which saw forestry in itself of such social and economic importance that financial considerations should not be allowed to hinder "sound forestry practices."

Helliwell (1974), Price (1973) and Webster and Gordon (1975) argue that the so-called market rate of interest over-emphasizes the short run (or, as Pigou (1932) denotes, is "myopic"). The role of public forestry investments is often not just timber production; indeed, this may at times be a minor objective. One potential goal of public forestry investment, and the one which Webster and Gordon (1975) appear to emphasize, is the preservation of options of resource use in the face of an uncertain future. Leslie (1967) suggests that myopia as applied to these goals, combined with uncertainty, may be adequate reason for calling forth a social discount rate.

Economic theorists have until recently dominated the debate over public discount rates, and have by-and-large left the forestry profession in the dark concerning appropriate discount rates for public forestry investment. Two major thrusts emerge from the many methods that economic theorists have suggested for determining discount rates for public investments. The first approach is the "Social Time Preference" rate, which rejects the market rate as a "norm" or optimal rate, and

\footnotetext{
3Marty and Newman (1969) indicated up to $15.4 \%$ return on investment for intensified forest management on National Forests in the United States. For example, coastal Douglas-fir (Site I) could return $9.2 \%$, to intensive management.

Marty (1973) indicates the impact of increasing price expectations. Looking at intensification of management (\$1/acre/year) on Site II Douglas-fir, the rate of return on investment rises from $9.6 \%$ at a price index of 115 to $21.0 \%$ at a price index of 225 .
}

${ }^{4}$ Some economic purists would accuse the author of performing a "value judgment" here. I would prefer, after $\mathrm{Ng}$ (1972) to call this a "subjective judgment of fact" (defined as a factual statement testable only under ideal conditions). Davis and Bentley (1967) and Shaffer (1969) would also be appropriate authorities to whom the author could appeal. For the sake of the record it should be noted that other "subjective judgments of the record, it should be noted that other "subjective judgments of fact"
appear throughout this paper. 
attempts to determine a social discount rate by political decision. The second is the "Opportunity Cost of Capital" rate, which is a modification of prevailing market rates in the private sector of the economy.

\section{Social Time Preference}

Proponents of social time preference (Feldstein 1964; Marglin 1963, 1968; Pigou 1932) reason that the time preference of individuals, reflected in market interest rates, can be used neither to evaluate society's consumption at different points of time nor its collective investment. Not only does an individual favor present consumption of his generation over future generations, but he is even more biased in favor of his own consumption with respect to future generations. It has been suggested that an individual has, in fact, two kinds of time preference: one governing his own consumption-savings decisions, and seldom extending beyond his lifetime; and the other, social conscious, which allows him to sacrifice some consumption for future generations, mindful that his contemporaries (through the political decision) are doing the same thing and he is not working in isolation. Thus, there is no inconsistency in a person borrowing at high rates of interest so that he can increase his own present consumption, while at the same time voting to spend tax money on public projects from which future generations will benefit, because he knows that other individuals will be pressured into similar actions. This psychic gain from others' investments often outweighs any sacrifice an individual may feel.

Social time preference, therefore, emerges from a collective social and political decision, and may diverge sharply from the market rate. It is only when individuals' private and social discount rates are equal - when they feel that the individual consumption-savings time preference is correct for every individual in society - that the market rate becomes significant for public investments.

Thus, the main argument for a social time preference is that the market does not provide accurately for the future, and does not reflect the social marginal cost of using capital today so that it is not available at some future date. However, this collective willingness to transfer, by low social discount rates, more income from present to future than would have accrued under normal market rates has been argued to be neither logical nor equitable, since future generations may well be wealthier in terms of per capita income or technology than the present one. In this case, the appropriate approach to deriving a social discount rate may be the following.

\section{Opportunity Cost of Capital}

The opportunity cost of capital may be defined as the value of the best alternative use to which this capital can be put. It has been argued that public investment will be inefficient if the discount rate in evaluation of these investments is lower than the marginal return expected from simi- lar investment in the private sector.

Some economists (e.g. Herfindahl and Kneese 1974) protest a social rate of discount based on social time preference. They state that such a rate is valid only insofar as benefits produced are social rather than commercial (Leslie (1947) argues that many forestry benefits are social, rather than commercial.). Moreover, they argue that public investment has a strong impact on the private sector and may completely offset potential private investment so that there is no increase in total investment. ${ }^{5}$ Also, by diverting private funds to low-return public investments, there could be misallocation of resources between sectors.

Marglin (1963) clearly sees the problem of public investment displacing "better" opportunities in the private sector and makes allowances for it in his formulae. Using the marginal social discount rate to maximize the present net worth of the public investments, but incorporating an opportunity cost which reflects the weighted social value of the benefits from the displaced private investment, Marglin is able to indicate the minimum present value which public investment must earn in order to maximize the returns to society from both public and private endeavors. Obvious operational difficulties arise in trying to determine these values.

Theoretically, the market interest rate only allocates resources efficiently in a perfectly competitive market. A basic tenet of perfection in an economic market is the perfect knowledge foresight of all transactors, and this is conditioned by complete certainty. It follows that lending and borrowing rates will be equal, and that the internal rate of return on an investment will, at the margin, always equal the market discount rate. No externalities can be present to prevent the free functioning of market equilibrium of supply and demand. There can be no economies or diseconomies in production, and no intangible costs or benefits to confound the markets. Only then will social and private costs and benefits be equal.

Our economy is no such Utopia, and the array of rates and returns we observe on the market reflect these imperfections. The main factors responsible for the divergence in the rates are risk, inflation, taxes and externalities in the market. Economists such as Arrow (1969), Baumol (1968) and Harberger (1968) favor modifying and combining various market rates to determine the appropriate discount rate to be used in public investment. By taking these factors into account in some way, they help to arrive at a point where investments face the same theoretical opportunities in the public as in the private sector in evaluation.

\section{A Choice To Be Made}

Considerable investment in intensified forestry should be made in B.C. if the province wishes to continue to participate in growing world markets.

${ }^{5}$ Given the high $(95 \%)$ proportion of public forest land in B.C., such an argument in this case may be speclous. 
Examination of economic theory has indicated the crucial inter-relationship of time and discount rate and has attempted to arrive at ways of deriving an efficient and equitable discount rate for public investments.

Teeguarden (1976) asks a very pertinent question, and provides some partially satisfactory answers, the sum of which is contained in the following rather extensive quotation:

"Is the rate of interest issue merely a toy for the economists, a toy that has no relevance at all to B.C. timber policy makers? In one way, it is. The decision to hold land under Crown control was a decision to follow a different developmental path than would have been the case had the lands been held by private persons. Thus the price signals we observe in the economy, including the level of interest rates, are not necessarily appropriate guides to public policy. Yet there is need for investment criteria which correspond in form to those in the private sector. Moreover, it is clear that the rate of interest chargeable against investments in B.C. forests is not anywhere near zero. But how much above zero? ... there is a case, I think, for working with two rates of interest: a relatively low rate for strategic, long-range investment planning for developing productive capacity and a second higher one for planning depletion of the surplus old-growth stock. The rationale is fairly simple. The low rate will assure that adequate funds will flow into the timber resource to develop it to the point where the marginal rate of return about matches the real marginal rate of capital productivity in the economy. It also reflects the public mandate to follow a conservative policy in forest resource management. The justification for the high rate is the urgent need to convert rapidly, subproductive surplus growing stock to capital which can be reinvested to meet the demands for public services with high social time preference in the areas of education, transportation, health, welfare, and so forth."

Thus, while the question is certainly not answered conclusively, and Teeguarden's viewpoint is open to argument, we are one step further along to a solution. However, the whole issue is clouded by traditional institutional outlooks, biological uncertainties, and the multitude of economic uncertainties and ambiguities that face government and industry.

In the face of these uncertainties, however, this much seems certain. If B.C. is to retain its prominent position in a growing world forest economy, investments in intensified forestry appear to be needed. These investments, if evaluated by benefit-cost analysis under "market" or "market derived" discount rates could well not be made. The choice, then, seems to be to evaluate forestry investments under a "social discount rate" as an incentive to maximizing the long-term growth of the province, and a higher rate to encourage liquidation of overmature and underproductive timber "capital", and maximizing present social welfare.

\section{References}

Arrow, K. J. 1969. The social discount rate. In: Cost benefit analysis of manpower decisions. Inst. for Ind. Rel., Queen's Univ. pp. 76-88.

Baumol, W. J. 1968. On the social rate of discount. Am. Econ. Rev. 58: 788-802.

Davis, L. S. and Bentley, W. R. 1967. The separation of facts and values in resource policy analysis. J. For. 65: 612-620.

Dobie, J. 1976. Economics of decadent cedar-hemlock utilization and rehabilitation in the B.C. Interior. Dept. of Env., Can. For. Serv., Inform. Rep. VP-X-156.

Feldstein, M. S. 1964. The social time preference discount rate in cost-benefit analysis. Econ. J. 74 360-369.

Fernow, B. E. 1902. Economics of forestry, 5th ed. Thomas Y. Crowell Co., New York.

F. L. C. Reed and Associates. 1973. Canada's reserve timber supply: the location, delivered cost, and product suitability of Canada's surplus timber. Dept. IT\&C, Ottawa.

Fritz, E. 1931. Compound interest in forestry. J. For. 20: 442.

Harberger, A. C. 1968. On measuring the social opportunity cost of public funds. In: The discount rate in public investment evaluation. W. Agr. Econ. Research Council, Report No. 17.

Helliwell, D. R. 1974. Discount rates in land-use planning. For. 47: $147-152$.

Henderson, J. M. and R. E. Quandt. 1971. Micro-economic theory: a mathematical approach, 2nd ed. McGraw-Hill Book Co., Toronto. pp. 254-292.

HerfindahI, O. C. and A. V. Kneese. 1974. Economic theory of natural resources. Charles E. Merrill Publishing Co., Columbus, Ohio.

Jaakko Pöyry and Co. 1975. Evaluation of global forest resources and markets for forest products: analysis of potential forest products in British Columbia. Dept. of Lands, Forests and Water Resources, B.C. Forest Service.

Keays, J. L. 1975. Projections of world demand and supply for wood fibre to the year 2000. Tappi 58(11): 90-95.

Leslie, A. J. 1967. Cost-benefit analysis in relation to plantation development programmes. Aus. For. 31: 19-32.

McKillop, W. 1976. Analytical techniques and social con. straints in policy formation. In McKillop, W. and W. J. Mead (eds.) Timber policy issues in British Columbia. U.B.C. Press, Vancouver. pp. 124-131.

Marty, R. J. 1973. Economic effectiveness of silvicultural investments for soflwood timber production. In: Report of the President's advisory panel on timber and the environment. Supt. of Doc., Wash. D.C. pp. 141-147.

Marty, R. J. and W. Newman. 1969. Opportunities for timber management intensification on the national forests. J. For. 67: 482-485.

Marglin, S. A. 1963. The social rate of discount and the optimal rate of investment. Q. J. Econ. 77: 95-111.

Marglin, S. A. 1968. The discount rate in public investment evaluation. In The discount rate in public investment evaluation. W. Agr. Econ. Research Council, Report No. 17.

$\mathrm{Ng}$, Yew-Kwang. 1972. Value judgments and economists' role in policy recommendation. Econ. J. 82: 1014-1018.

Oxholm, A. H. 1931. The attitude of Sweden toward compound interest in forestry calculations. J. For. 29: 443-44.

Persson, R. 1974. World forest resources: review of the world's forest resources in the early 1970's. Dept. of Forest Survey, Royal College of Forestry Stockholm, Research Note 17.

Pigou, A. C. 1932. The economics of welfare, 4th ed. MacMillan, London.

Price, C. 1973. To the future: with indifference or concern?the social discount rate and its implications in land use. J. Agr. Econ. 24: 393-398.

Roth, F. 1916. Business rate of interest and rate made by the forest. For. Quarterly 14: 255-259.

Shaffer, J. D. 1969. On institutional obsolescence and innovation - background for professional dialogue on public policy. Am. J. Agr. Econ. 51: 245-267.

Teeguarden, D. 1976. Comments and viewpoints. In: McKillop, W. and W. J. Mead (eds.) Timber policy issues in British Columbia. U.B.C. Press, Vancouver, pp. 233-239.

U.S. Forest Service. 1975. RPA: The nation's renewable resources - an assessment, 1975. U.S. Dept. Agr.

Webster, H. H. and J. C. Gordon. 1975. Timber, time and money: an opinion. J. For. 73: 265-267. 